\title{
Evolution of the city of Irkutsk economic-geographic position in various scales
}

The well-known notion of economic-geographic position seems to be a good instrument of regional analysis, although qualitative. The two principal peculiarities of this method are, according to the classics (Nikolay Nikolayevich Baransky [1], Isaak Moiseyevich Mayergoyz [2]), "playing scales" and historical, evolutionary approach.

An interesting idea was suggested not long ago by Professor Andrey Treyvish (Mayergoys's direct disciple) [3]. He notes that, unlike a historian or an economist, a geographer cannot concentrate the investigation on some given scale: only studying the object in various dimensions, can he or she make conclusions and, at all, see the object more or less adequately.

Let us try these ideas on the example of a concrete case. Analyzing the problems and prospectives of Irkutsk, a 600-thousand (although steadily depopulating - and this is one of the problems) city in East Siberia (see fig. 1), to understand them comprehensively, we meet the necessity of differentiated evolutionary approach considering various aspects and scales.

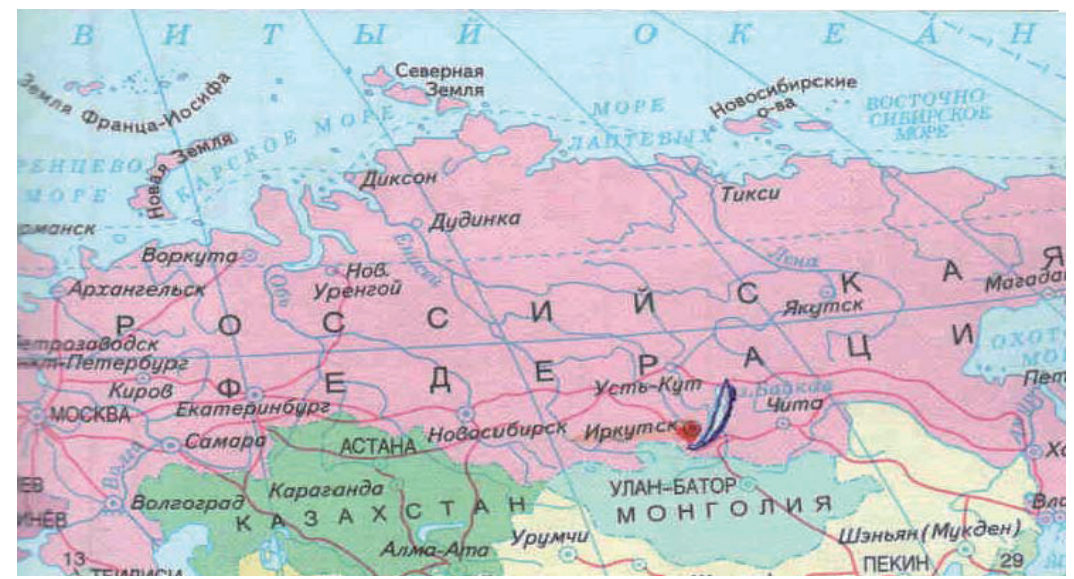

Fig. 1. Geographic macro-position of Irkutsk 
Irkutsk in Europe. Geographically located in Asia, it is, culturally and mentally, a Russian city, and Russia is a European country. The latter idea, shared by the author of this article, is not unanimously adopted, either in Russia, or in Western Europe, and the discussions on this item are of political significance.

Russia seems to be the only country in the World having doubts as to its belonging to Europe. Speaking about the countries lying to the West of it, people usually do not analyze the history of these countries (for example, whether they have survived all the stages of European history - obviously, the Balkan states have not) or their level of culture, level of democracy, etc. (even if we forget that Nazi Germany or Spain under Franco couldn't be labelled as "non-European", neither can be contemporary Baltic states that undertake unprecedented and certainly uncivilized measures as to their inhabitants - legal migrants of the Soviet times). Geographically, they all are parts of Europe.

On the other hand, Asian or African countries do not pretend to be European - they obviously belong to other civilizations. Neither do the USA or Australia, but for different reasons. They are not European geographically, and nobody has any doubts as for their common culture with France and Germany.

But Russia is situated in Europe by its main, most populated and historically "determining" part. It is the member of various European organizations, whether political or sportive. Historically, its culture takes its origin in Byzantium and has so much in common with other Orthodox countries of Europe. Russian children are brought up reading the same fairy tales that are read in Germany, England, Poland, Italy (are Chinese or Egyptian children too?), later the same adventure books, science fiction, then plays and novels, and they go on being grown-up, with the same films (not Indian, with their Oriental sentiments), the same music, the same fine art. Certainly, the intellectual baggage of the Russian people contains also some specifically national books or films, but it is also so for Polish, Danish or German people.

Let us look at it from the other side. Russian writers, composers, artists, architects, as well as film, theatre, opera and ballet directors, are well known in Europe and form an integral part of European culture.

So, why does the very question emerge?

Inside Russia, there exists the opinion that the country isn't either Europe or Asia but something special and unique. It may seem (to somebody) rather attractive. But what does it mean? People who promote this idea mean very definite things: Russia doesn't need European political and economic models, its way is the destiny of an authoritarian state the interests of which are of highest priority before human rights; Russian culture that has been polluted with alien (Western, Jewish and so on) influence needs purifying; Russian Orthodox church must replace Communist party as the totalitarian body forcing its ideology to the society; Russian empire should be revived and have more influence in the World. It is quite natural that some other people (including the author of this article) dislike it.

Different are the reasons why partisans of Russian special and non-European way exist in Western Europe. They treat Russia, independently of its actual government, as a dangerous neighbour that can never be anything else but a potential aggressor; luckily, NATO exists to defend Europe and its values, and let Russia go its specific way somewhere behind the iron curtain.

This position is quite understandable. But is it reasonable? The questions are worth thinking about: if certain forces in Russia, for whom it is favourable, win, will it be good for 
Europe? Wouldn't it be better to support other forces - that is, those who want to see Russia a European country?

And if Russia is a European country, it is clear that our resolution should be true not only for the regions West of the Urals, but for the whole territory of the country, including Irkutsk.

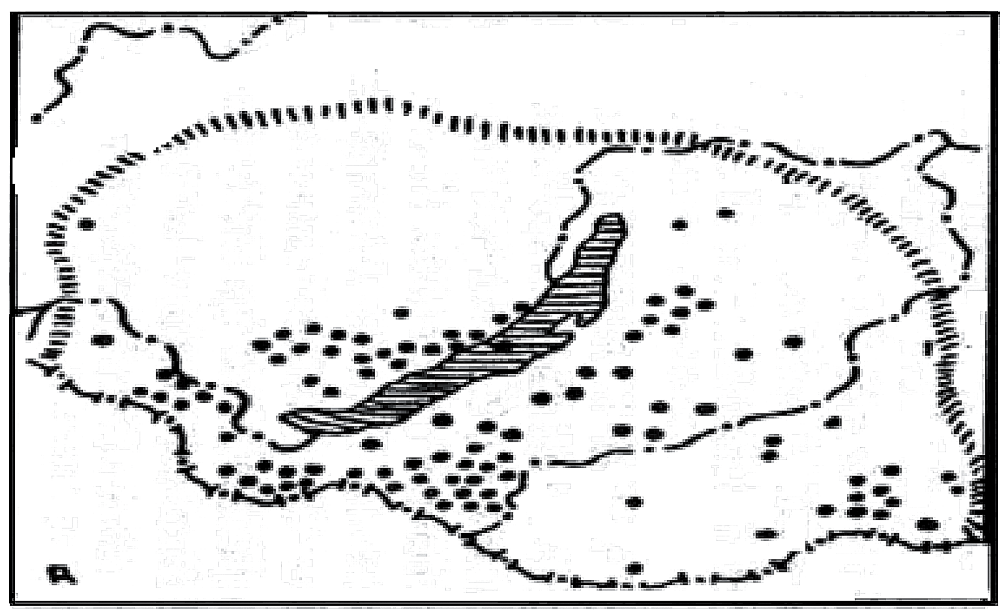

Fig. 2. Settling of Buryat people: in our days (dots) and historically (approximate maximum border)

Long ago, in the $17^{\text {th }}$ century, Russian "zemleprokhodtsy" ("land-passers", a special word for the category of people who did it, which included Cossacks, fugitive peasants, merchants, hunters, searchers of adventures, travellers, state officers, etc) reached the land inhabited by Buryats, a nomadic people of Mongol origin. The Russian in those times called them "Bratskiye lyudi" (this way they pronounced the word "Buryatskiye"), which can be interpreted also as "Brotherly people". By the way, the name of well-known Bratsk (originally Bratskiy ostrog) stems from this very word and used to mean "the fortress in the Buryat land".

Neither zemleprokhodtsy, nor Buryats in the $17^{\text {th }}$ century could recognize that their contact was the contact of two great civilizations. Luxurious scholars and poets of India and China hadn't perhaps even heard about those wild nomads while Buryats hadn't heard about the palaces of Beijing or Delhi (only the most educated of them, and living far to the East of Baikal, had got some acquaintance with Buddhism in its Mongolian form).

Similarly, Russian Cossacks had known nothing about Paris, London or Rome. And their enlightened contemporaries in the West were not interested in those Barbars. But still, without knowing it, both groups (zemleprokhodtsy and Buryats) were peripheral representatives of respective civilizations.

During three and a half centuries, both Russian and Buryat cultures have changed. The former is well known in the World, it has been and will be discussed in this very article. As for the latter, its evolution was typical for many ethnic groups of the Russian Empire and the Soviet Union. Briefly speaking, they were partially assimilated by Russians and became a part of one great and complicated nation, and this has made them much more European, together with saving their ethnic identity and traditions. 
They wear European clothes and they all speak Russian fluently while for more than half of them Russian is the mother tongue; as to the level of education, Buryats rank $2^{\text {nd }}$ among the peoples of Russia (after Jews). In the $20^{\text {th }}$ century, they gave Russian literature such a prominent figure as Irkutsk playwright Alexander Vampilov, with all-Union and, probably, worldwide fame (and to Ukraine - its former Prime-Minister and now Minister of Defence, Yury Yekhanurov).

At the same time Buddhism is widespread among the Buryats to the East of Baikal, and shamanism - to the West. More and more Buryats study their historical language, give their children Buryat names and so on (in Soviet times the number of such people tended to decline, especially among Western - that is Irkutsk - Buryats, who had been baptized into Orthodoxy in the $19^{\text {th }}$ century, though rather formally, but in their case, names and surnames of Russian origins were and are characteristic).

Geographically, most Buryats live in the Buryat Republic, but a significant number also live in Irkutsk Oblast (just to the West of Baikal) and Chita Oblast (now Transbaikalian Kray). It is shown in table 1(source - [4]. We can also see that a lot of them have dispersedly settled throughout Russia and the Soviet Union (we have no data on Buryat diaspora in the USA but it does exist). Additionally, the dispersion of Buryats was the integral part of Soviet (European in their character) migrations.

Tab. 1. The number of Buryat population

\begin{tabular}{|l|c|c|}
\hline \multicolumn{1}{|c|}{ Territorial units } & $\begin{array}{c}\text { Number of Buryats, } \\
\text { thousand }\end{array}$ & $\begin{array}{c}\text { Percentage } \\
\text { (inside Russia) }\end{array}$ \\
\hline Buryat Republic & 249,5 & 59,7 \\
\hline Irkutsk Oblast & 56,6 & 13,6 \\
\hline $\begin{array}{l}\text { Chita Oblast (now Transbaikalian } \\
\text { Kray) }\end{array}$ & 47,0 & 11,2 \\
\hline Yakut Republic & 8,0 & 1,9 \\
\hline Other subjects of Russian Federation & 56,6 & 13,6 \\
\hline Russian Federation, total & 417,7 & 100,0 \\
\hline Other ex-Soviet countries & 3,9 & - \\
\hline Mongolia & 35,0 & - \\
\hline China & 10,0 & - \\
\hline
\end{tabular}

Now, being a less important centre of Buryat culture than Ulan-Ude (the capital of the Buryat Republic), Irkutsk is a bigger cultural (scientific, educational) centre in general, so the two cities are complements to one another.

Irkutsk in Russia. Russia is an eccentric country in its structure, and Irkutsk, being situated geographically in the very centre of it, for Russia is a Siberian city, that is an Eastern one. As one teacher of geography said (in the Soviet times), the negative characteristic of Eastern Siberia economic-geographic position is that it lies far from the Centre (that is, Moscow), but its benefit is that it is nearer to the Centre than the Far East.

So, for Russia, Irkutsk is a Siberian city. The meaning of this fact has changed, while Siberia used to be or is (in fact or in mass consciousness, or both): 
- the place of exile, prison and concentration camps,

- the vast land of abundant resources and immense perspectives, the main reserve of national growth (in the Soviet times, a very popular slogan was the one put forward by M.V. Lomonosov in the $18^{\text {th }}$ century: "Russian might will increase by Siberia"),

- a burden, a brake on the way of civilized development. The latter position has been expressed by some American [5] and Moscow experts but is, of course, unacceptable for Siberians [6].

In this scale (that is, seen from Moscow), Irkutsk isn't simply a Siberian city - it is one of Siberian cities, hardly having any individuality.

Irkutsk in Eastern Asia. Since its very foundation, Irkutsk has served as a frontier point of Russian and, hence, European civilization in Asia, as an intercultural and trade bridge, for contacts not only with indigenous Siberian peoples (Buryats among them) but also with China and Mongolia.

Returning to the ideas expressed above, we can say that Europe in our days is something more than just a continent. It is an axiological value. Let me give here an interesting idea of a young Mongolian geographer Baljinnyam [7]: if Russia integrates into European structures, it will be good for Mongolia, as the latter will become nearer to Europe.

Today, Irkutsk meets competition of some other Siberian cities in this "bridge" function, but is competitive enough.

There exist some other aspects of this issue. Nowadays, the position of Irkutsk has slightly changed (in comparison with the statements given above). The Far East, in the conditions of market economy, is not only far from Moscow, it is near Japan, Korea and China, and this proximity gives some new benefits, unknown under centralized administration; and some new problems, too.

Among the new opportunities is the possibility to import Japanese cars. This generates a problem that is unknown to any country in the World except Russia. It is well known that in Japan, unlike most other countries, left-side traffic exists. Respectively, Japanese plants produce cars with a right wheel for domestic market and with a left one for export to Europe (except Great Britain), America and so on. But Russian small businessmen import secondhand cars bought in Japan, in Vladivostok they are much cheaper than American or European cars, cheaper (and of much higher quality) even than those produced in Russia. It is an opportunity for both customers and businessmen, one that doesn't exist in Moscow.

The Government has tried many times to forbid using such out-of-standard cars, but by now couldn't succeed because only such cars are in use in Vladivostok and other cities of the far East.

A problem of another type is Chinese immigration (both legal and illegal) and steady fear than once this land will be conquered by the Chinese.

And what about Irkutsk? All these problems and opportunities are present here as well, but the problems are a bit less acute and the opportunities a bit less beneficial.

Irkutsk in the ex-Soviet Union. The crash of the Soviet Union has brought numerous changes in the communications inside the territory which had been much more an integrated country than an "empire" (and today's Russia merely a part of this entity). The latter aspect has been ignored not only by nationalistic forces in the new independent states but also by a significant part of intellectuals in the West and even within Russia (usually in Moscow).

Obviously, the Soviet Union was, according to its Constitution, a federation of 15 juridically equal republics having more in common with the United Kingdom of Great Britain and 
Northern Ireland than with the British Empire. Certainly, there existed some (or even very many) elements of inequality and domination of one nation and one republic (just like in the UK). In some cases it was quite natural, in some cases it could and was to be corrected in the processes of democratization.

To confirm the statement about an integrated country one should analyze, first, the processes of migration inside common juridical space (nationalists and separatists have been using the word "migrants" as an accusative label, but, standing on the soil of European liberal values, we must recognize that free migration is one of them) and, secondly, what should be called Soviet culture. The latter is not the same as Russian culture. If we take literature and cinema (the spheres most connected with language), we can see such phenomena as authors writing (making films) in Russian about the life of their nations or even in respective languages, but these books or films were the facts of the whole-Union cultural life.

All this must be taken into account - otherwise the analysis cannot be comprehensive - as well as a quite unexpected aspect: the losses of the former Soviet republics. Just one of these losses is the fact that under the Soviet Union they all belonged to Europe (and we have shown that this is a valuable position) but now some of them do not.

The specific role of these processes for Irkutsk has still been underanalyzed.

But we can mention just one aspect. It has been said that there exists the problem of Chinese immigration. Such problems, social, cultural and psychological in their nature, are familiar to all the developed countries. It exists in Irkutsk, too. Here we find migrants not only from China but also from former Soviet republics. Many experts believe that migration of Tadjiks or Armenians would be much more favourable for Irkutsk, as those ex-Soviet people know (to be more exact, have known or used to know) Russian and, at all, due to long staying in one state, are more close to European culture.

Irkutsk in Siberia. A typical feature of big Siberian cities is localization in a place where Transsiberian Road is crossed by one of great Siberian rivers: Omsk on Irtysh, Novosibirsk on Ob, Krasnoyarsk on Yenissey, Ulan-Ude on Selenga, Khabarovsk on Amur. Irkutsk, on Angara, is one of them. Like other cities of this type, it has served as the base for investigating, exploring and settling the territories first to the East and later (by now) to the North of it.

Officially, Irkutsk is situated in the East-Siberian economic region. But there have existed two rather popular variants of altering the scheme of regionalization. The plot of these variants as well as the character of their popularity reflect changes in public understanding of regional structures and Irkutsk's role in them.

When we speak about Angara-Yenissey economic region (uniting Irkutsk Oblast and Krasnoyarsk Kray), we address the project once put forward by a prominent Soviet geographer, Nikolay Nikolayevich Kolossovsky [8] in Moscow University and actively advocated in 1960 s - 70s by an Irkutsk scientist, Victor Alexandrovich Krotov [9]. The idea of this project was complex utilization of the resources of the two river basins for forming a regional territorial-productional complex on the basis of the power-productional cycle (Kolossovsky's terms) in the all-Union system of economy (see fig. 3). Now, under market economy, this idea has been in fact forgotten. 


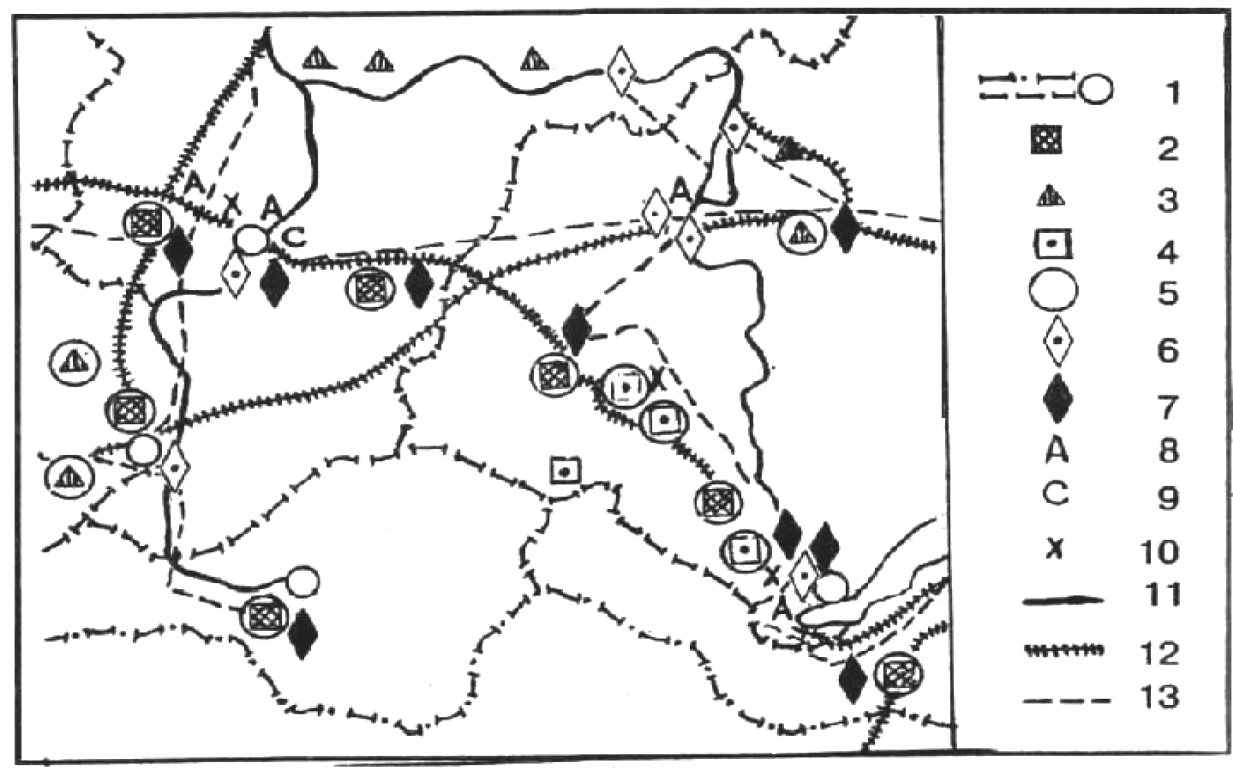

Legend: 1 - state and adminıstratıve borders, admınıstratıve centers; $L$ - coal deposits; 3 - ore deposits; 4 - chemical raw materials deposits; 5 - various deposits under exploitation; 6 - hydropower stations ; 7 - thermal power stations; 8 - aluminum and alumina works; 9 - power-intensive special steel works; 10 - power-intensive chemicals works; 11 - principal rivers; 12 - railroads; 13 - electrical transmission lines

Fig. 3. The hydropower-productional cycle of Angara-Yenissey region

Even in those times, there existed an alternative idea of dividing Eastern Siberia otherwise - into Middle Siberia with Krasnoyarsk, and Baikal region, uniting Irkutsk Oblast with Transbaikalian Buryat Republic and Chita Oblast [10]. This variant gained enormous popularity in the years of Perestroyka - in late 1980s. It was popularity among common people - unlike the former variant, popular among researchers. Democratic mass-media advocating the idea stressed that defence of Baikal natural environment was a much more important task than forming territorial-productional complexes. Some authors (including the author of this article [11]) noted that it would be an inter-ethnic (Russian with compact Buryat minority) region, which could become an innovation in the Soviet administrative system).

Irkutsk in its administrative region (Oblast). For decades and even centuries, Irkutsk has been an administrative, cultural and trade centre with an official hinterland, almost stable in its borders (fig. 4). Since 1960s, a new sub-regional centre, Bratsk, has been developing in the Northern (larger but less populated and industrialized) part of the Oblast. In our days the ways of the two parts are still more diverging.

In the South, population is respectively dense and some potential for post-industrial development can be found. In the North, the only hope for improving economic and social situation is proceeding with industrial specialization, including the development of new natural resources.

Reforming administrative division is not an actual problem in today's Russia, but, in our opinion, it is inevitable, sooner or late. 


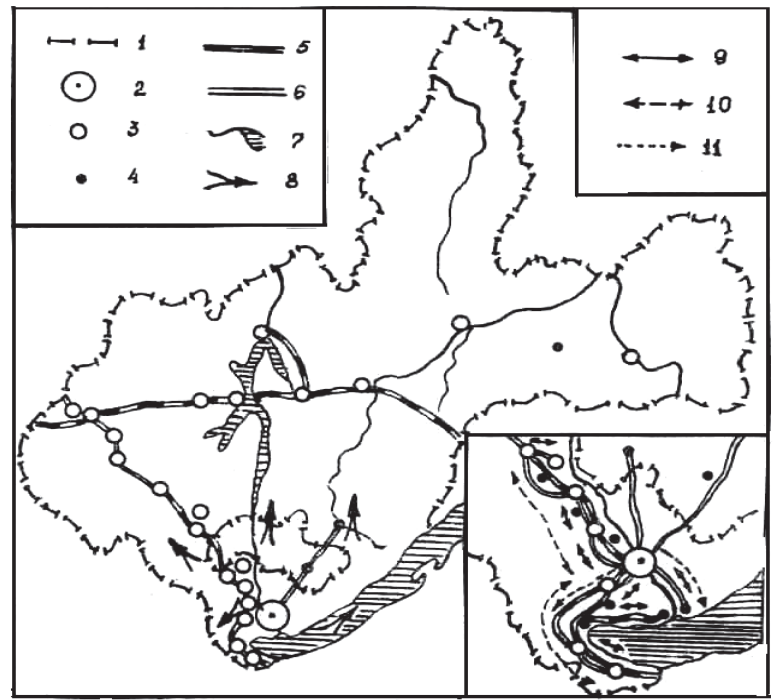

Legend: 1 - borders of the Oblast and Buryat Autonomous unit (had existed by 2008, now part of the Oblast); 2 Irkutsk, 3 - other towns; 4 -important urban settlements; 5 - railroads; 6 - highways; 7 - navigable rivers and reservoirs; 8 -main directions of contacts of Irkutsk with the periphery of the Oblast; 9 - directions of labor (everyday) commuting; 10 - directions of less regular (once a weak or a fortnight) trips; 11 - directions of recreational trips

Fig. 4. Economic-geographic position of Irkutsk in the Oblast and (in the fit in map) in the agglomeration

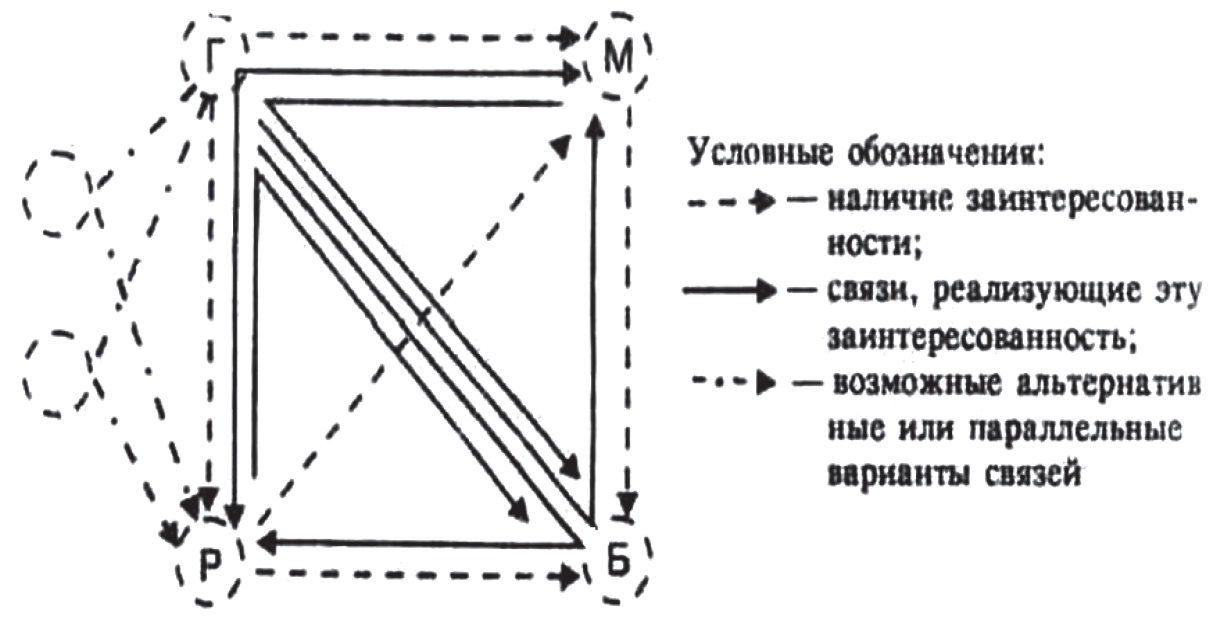

Fig. 5. Formalization of the idea of Irkutsk development as a city: 1 - presence of interest, 2 - connections realizing this interest, 3 - possible alternative or parallel variants of connections 
Irkutsk and Baikal. The lake Baikal is worldwide known and popular, and Irkutsk, only $60 \mathrm{~km}$ from its banks, exploits and promotes the image of "the city on Baikal" intensively in order to attract the attention of authorities, investors and tourists.

About 20 years ago, the author of this article put forward a simple formalization of the "idea" of Irkutsk development as a city (fig. 5). It presumes the following:

- the city $(\Gamma)$ is interested in direct contacts with the World $(\mathrm{M})$, in direct attention to it on the part of the World;

- to realize it, the city needs to become the centre of a major region $(\mathrm{P})$, distinguishable in the scale of the World and trusting the city to represent the whole region;

- solving the latter task will be (perhaps) possible if the city manages to position itself as "the city on Baikal (Б)", as the regional population (a major part of it) evaluates Baikal very high, much higher than Irkutsk by itself; such a positioning must be a problem because of competition (the first competitor is Ulan-Ude);

- this very positioning is needed to attract the interest of the World: wanting to see Baikal, to recreate here, to investigate it, even to meditate near it, you must first come to Irkutsk;

- some other ideas and images can exist alongside with this or even instead of it [12].

Now it is clear that some non-obvious problems exist here that make the task discussed above rather complicated.

The most tricky aspect is that (thanks to Dr. Konstantin Lidin for the idea [13]), though attracting to Irkutsk in macro-scale, Baikal seen in micro-scale, where $60 \mathrm{~km}$ distance does play some role (or, more simply, when a tourist has arrived in Irkutsk with such an understanding and sees that he or she can take a bus and go directly to Baikal or stay in the city), Baikal can rather distract from Irkutsk.

Irkutsk in its agglomeration. The core of the Southern (mentioned above) part of the Oblast is Irkutsk linear urban agglomeration (see fig. 4, the fit-in map), concentrating up to 80 per cent of the Oblast population and its nearly whole intellectual potential. The agglomeration is still in the stage of formation, the level of communicational infrastructure has been by now unsatisfactory.

Irkutsk and Poland. This topic doesn't seem obligatory when we speak about Irkutsk. But, playing scales, we can come to it too.

The story of Poles coming to Siberia is not a Christmas tale. Mostly, they were exiles after Polish rebellions. But history cannot be a Christmas tale. The fact is that now there is a Polish village Wierszyna not far from Irkutsk; there are several villages in the Oblast inhabited by an interesting and enigmatic ethnic group whom Irkutsk historian Professor Boleslaw Szostakovicz [14] believes to be of Polish origin (their grandfathers came to Siberia from Volyn, they call themselves Holendry and believe that their roots are somewhere in Holland, their names sound German and their under-investigated language sounds like something intermediate between Polish and Ukrainian); there are two kostiols in the city (a special Russian word for a Polish church; for the majority of citizens, those are just "Polish" churches, rather than "Catholic" - see fig. 6); and of great popularity and respect are the names of Jan Dominik Czerski, Benedykt Dybowski and Aleksander Czekanowski - political exiles and famous explorers of Siberia. 

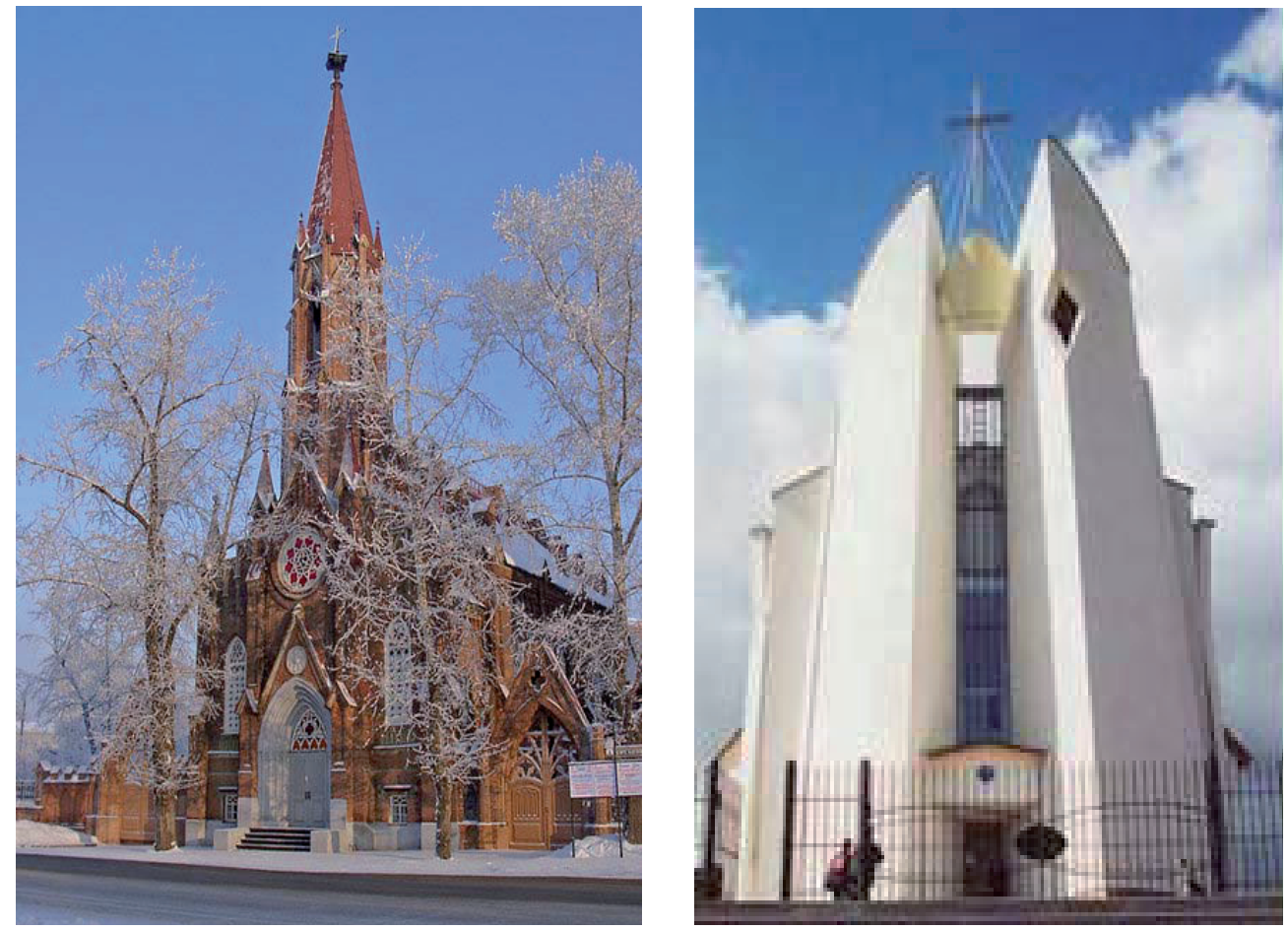

Fig. 6. Polish churches in Irkutsk: first, built in the 19th century by Polish exiles, now combining two functions and serving as well as an organ concert hall (left); and second, new-built

From the practical point of view, isn't it the reason for tourist business in Irkutsk to deal with a special segment of potential guests of the city and to carry out special promotion!

\section{References}

Atlas Respubliki Buriatiya. - M. - Novosibirsk, 2000. - 48 p.

Baljinnyam D. Ekonomiko-Geograficheskiy Potentsial Mongolsko-Rossiyskikh Vnieshnieekonomicheskikh Sviaziey: Avtoref. diss. (cand. geogr. nauk). - Irkutsk, 2006. - 24 p.

Baransky, N.N. Ekonomiko-geograficheskoye polozheniye. - In: N.N. Baransky. Izbrannyie Trudy. Stanovleniye Sovietskoy Ekonomicheskoy Geografii. - M.: Mysl, 1980. - P. 128-159 (first published in 1939).

Dolzhnykh, V.N. Industriya Pribaikalya i Effektivnost Yeyo Razvitiya. - Irkutsk: Vost.-Sib. Kn. Izd-vo, 1967. $-184 \mathrm{p}$.

Gaddy, C., Hill, F. The Siberian Curse: How Communist Planners Left Russia Out in the Cold. Washington, DC: Brooking Institution Press, 2003

Jakobson, A.Ya. Baikalskiy region kak model territorialnoy organizatsii etnicheskoy politiki. - In: Geograficheskiye Issledovaniya Aziatskoy Rossii: Istoriya i Sovriemiennost. - Irkutsk, 1995. P. 182-184.

Jakobson, A.Ya. K razrabotkie kontseptsii razvitiya goroda Irkutska: gorod i region. - In: Kontseptsiya Razvitiya Goroda: Sotsialniye, Ekologicheskiye, Upravlencheskiye Aspekty. - Novosibirsk, 1991. - P. 32-58. 
Kolossovsky, N.N. Proizvodstvienno-territrialnoye sochetaniye (kompleks) v sovietskoy ekonomicheskoy geografii. - In: N.N. Kolossovsky. Osnovy Ekonomicheskogo Rayonirovaniya. - M.: Geografgiz, 1958 (first published in 1947).

Krotov, V.A. Nasushchniye zadachi soviershenstvovaniya ekonomicheskogo rayonirovaniya Sibiri i Dalniego Vostoka. - In: Problemy Ekonomiki Vostochnoy Sibiri. - Novosibirsk: Nauka, 1981 (first published in 1973).

Lidin, K.L., Jakobson, A.Ya. Megalopolis Cherembaik. - Project Baikal. - 2006. - № 9. - P. 3-8.

Mayergoyz, I.M. Zadachi izucheniya ekonomiko-geograficheskogo polozheniya. - In: I.M. Mayergoyz. Territorialnaya Struktura Khoziaystva. - Novosibirsk: Nauka, 1986. - P. 51-64 (first published in 1956).

Melnikova, L.V. Osvoyeniye Sibiri v Zierkale Libieralnoy Ekonomicheskoy Nauki. - In: Problemniye Territorii Resursnogo Tipa: Aziatskaya Chast Rossii. - Novosibirsk: Izd-vo SO RAN, 2005. P. $34-47$

Treyvish, A.I. Gorod, Rayon, Strana i Mir. Razvitiye Rossii Glazami Stranovieda. Novyi Khronograf, 2009. $-372 \mathrm{p}$.

\section{Evolution of the city of Irkutsk economic-geographic position in various scales}

The notion of economic-geographic position seems to be a good instrument of regional qualitative analysis. The two principal peculiarities of this method are "playing scales" and historical, evolutionary approach. These ideas are analysed on the example of a particular case, the problems and prospects of Irkutsk.

The following relationships are studied: Irkutsk in Europe, Irkutsk in the ethnic area of the Buryat people, Irkutsk in Russia, Irkutsk in Eastern Asia, Irkutsk in the ex-Soviet Union, Irkutsk in Siberia, Irkutsk in its administrative region (Oblast), Irkutsk and Baikal, Irkutsk in its agglomeration, and Irkutsk and Poland.

Prof. Anatol Jakobson

Irkutsk State Railway University, Russia

e-mail: yakobson_ay@irgups.ru 